\title{
PENGEMBANGAN BAHAN AJAR DENGAN KONTEKS ALAT BERBURU TRADISIONAL DAYAK TABUN DALAM MATERI BANGUN RUANG
}

\author{
Hedrian Pilimon $^{1}$, Muhamad Firdaus ${ }^{2}$, Hartono $^{3}$ \\ ${ }^{1), 2,3)}$ Prodi Pendidikan Matematika, Fakultas P.MIPATEK, IKIP-PGRI Pontianak \\ hpilimon10@gmail.com
}

\begin{abstract}
Abstrak
Penelitian ini bertujuan untuk mengetahui "Bagaimana pengembangan bahan ajar dengan konteks alat berburu tradisional dayak tabun dalam materi bangun ruang sisi datar pada siswa kelas VIII SMP Negeri 01 Ketungau Tengah". Dengan sub-sub masalah atau masalah khususnya dalam penelitian ini adalah bagaimanakah tingkat kevalidan, kepraktisan dan keefektifan bahan ajar dengan konteks alat berburu tradisional dayak tabun dalam materi bangun ruang sisi datar pada siswa kelas VIII SMP Negeri 01 Ketungau Tengah. Metode yang digunakan dalam penelitian ini adalah metode penelitian Research \& Development $(R \& D)$ dengan mengacu pada model 4-D yaitu Define, Design, Development, and Disseminate. Subjek uji coba dalam penelitian ini adalah siswa kelas VIII SMP Negeri 01 Ketungau Tengah dengan jumlah 29 siswa. Berdasarkan hasil uji coba terbatas yang dilakukan diperoleh bahwa 1) hasil validasi bahan ajar adalah $80,79 \%$ pada kategori valid, 2) hasil kepraktisan berdasarkan hasil pengamatan keterlaksanaan bahan ajar yang dikembangkan adalah 84,37 \% dengan kategori praktis, 3) hasil keefektifan bahan ajar adalah 68,96\% dengan kategori efektif. Sehingga dapat disimpulkan bahwa pada tahap uji coba terbatas dilaksanakan bahan ajar matematika dengan konteks alat berburu tradisional dayak tabun telah memenuhi kriteria kevalidan, keraktisan, dan keefektifan.
\end{abstract}

Kata Kunci: pengembangan, bahan ajar, alat berburu tradisional.

\begin{abstract}
This study aims to determine "How is the development of teaching materials with the context of traditional Dayak tabun hunting tools in the flat-sided building material for class VIII students of SMP Negeri 01 Ketungau Tengah". With sub-problems or problems, especially in this study, how is the level of validity, practicality, and effectiveness of teaching materials in the context of traditional Dayak tabun hunting tools in the material for building flat-sided spaces in class? VIII students of SMP Negeri 01 Ketungau Tengah. The method used in this study is the Research \& Development $(R \& D)$ research method concerning the 4-D model, namely Define, Design, Development, and Disseminate. The test subjects in this study were class VIII students of SMP Negeri 01 Ketungau Tengah, with 29 students. Based on the results of the limited trials conducted, it was found that 1) the results of the validation of teaching materials were $80.79 \%$ in the excellent category, 2) the results of practicality based on observations of the implementation of the teaching materials developed were $84.37 \%$ in the practical category, 3) the results of the effectiveness of the materials. Teaching is $68.96 \%$ with effective category. So, it can be concluded that in the limited trial stage, mathematics teaching materials in the context of traditional Dayak tabun hunting tools have met the criteria of validity, practicality, and effectiveness. Keywords: development, teaching materials, traditional hunting tools.
\end{abstract}

Received: July 28, 2021 / Accepted: December 01, 2021 / Published Online: December 30, 2021 
Jurnal Lebesgue : Jurnal Ilmiah Pendidikan Matematika, Matematika dan Statistika

Hedrian Pilimon, Muhamad Firdaus, Hartono

Volume 2, No. 3, Desember 2021 hal.245-255

DOI Artikel : 10.46306/lb.v2i3.80

\section{PENDAHULUAN}

Pendidikan adalah suatu usaha sadar yang dilakukan secara sistematis dalam mewujudkan suasana belajar-mengajar agar para peserta didik dapat mengembangkan potensi dirinya. Dengan adanya pendidikan maka seseorang dapat memiliki kecerdasan, akhlak mulia, kepribadian, kekuatan spiritual, dan keterampilan yang bermanfaat bagi diri sendiri dan masyarakat".

Pendidikan secara praktis tidak dapat dipisahkan dengan nilai-nilai kebudayaan terutama dalam menjaga dan melestarikan kebudayaan sendiri. Tujuan pendidikan adalah melestarikan dan meningkatkan kebudayaan itu sendiri. Artinya pendidikan dan kebudayaan memiliki hubungan yang sangat erat. Menurut Septian (Liliweri, 2002: 108) Kebudayaan adalah akumulasi dari keseluruhan kepercayaan dan keyakinan, norma-norma, kegiatan institusi, maupun pola-pola komunikasi dari sekelompok orang.

Dalam dunia pendidikan, matematika merupakan menjadi salah satu pelajaran yang penting. Tetapi nilai matematika cenderung selalu rendah. Kurang minatnya terhadap matematika merupakan salah satu penyebabnya. Penyebab lainnya ialah kurangnya kesadaran tentang matematika dalam kehidupan sehari-hari. Septian (Marsigit, 2015: 2) mengungkapkan dalam mengajarkan matematika formal (matematika sekolah), guru sebaiknya memulainya dengan menggali pengetahuan matematika informasi yang telah diperoleh siswa dari kehidupan masyarakat disekitar tempat tinggalnya. Hal-hal yang konkrit dan berhubungan dengan pengalaman sehari-hari dapat dijadikan sebagai sumber belajar yang menarik. Salah satu aspek yang dapat dikembangkan untuk inovasi pembelajaran matematika adalah kebudayaan.

Kebudayaan dalam masyarakat atau sub-etnis tertentu yang dilakukan dengan cara yang berbeda-beda merupakan suatu keunikan tersendiri bagi masyarakat atau subetnis tersebut. "Kebudayaan ini sering disebut kebudayaan daerah. Kebudayaan daerah adalah suatu sistem nilai yang menuntun sikap, perilaku, dan gaya hidup yang menjadi identitas dari suku bangsa itu sendiri”. Identitas yang dimaksud ialah ciri khas sub-etnis maupun masyarakat tertentu yang membedakan kebudayaannya dengan kebudayaan masyarakat maupun sub-etnis lainnya.

Sebagai contoh pada penelitian ini adalah etnis suku Dayak Tabun yang mempunyai kebudayaan yang cukup unik terutama pada alat-alat tradisionalnya. Alat-alat tradisional suku Dayak Tabun merupakan alat yang digunakan dalam kehidupan sehari-hari ataupun pada upacara adat istiadat tertentu masyarakat Dayak Tabun dengan berbagai macam kegunaanya 
Jurnal Lebesgue : Jurnal Ilmiah Pendidikan Matematika, Matematika dan Statistika

Hedrian Pilimon, Muhamad Firdaus, Hartono

Volume 2, No. 3, Desember 2021 hal.245-255

DOI Artikel : 10.46306/lb.v2i3.80

yang sekaligus sebagai simbol suatu daerah. Kebudayaan yang unik ini harusnya bisa diangkat dan dikembangkan sebagai bahan ajar dalam pembelajaran matematika di Sekolah.

Alat-alat tradisional Dayak Tabun sebelumnya diteliti konsep matematikanya oleh Dwi Pinardi Septian pada tahun 2017, Dwi Pinardi Septian (2017) menjelaskan bahwa alat-alat tradisional Dayak Tabun yang memuat konsep matematika adalah Bubu (Tabung), Lesung (Balok), Kisar (Tabung), Kelayak (Persegi Panjang), Entayak (Kerucut), Sangkuh Akai Aduh (segitiga), Tinja' jelu (Balok), Terabai (Trapesium Sama Kaki), Sirat (persegi Panjang), Baju Temeran (Persegi Panjang) dan Tanggui (Kerucut), Alat-alat tradisional tersebut hampir keseluruhan memuat konsep Geometri terutama untuk siswa sekolah menengah yaitu Bangun Ruang. Oleh karena itu hasil penelitian tersebut perlu diterapkan disekolah, agar pembelajaran matematika memiliki konteks kearifan lokal Budaya Etnis Dayak Tabun.

Penulis mengambil konteks dengan alat berburu tradisional suku Dayak Tabun ini agar siswa dapat lebih mengetahui hubungan matematika dengan hal-hal lain contohnya alat berburu tradisional Dayak Tabun ini. Namun pada kenyataannya, dalam pembelajaran terlihat siswa masih sulit menghubungkan materi yang mereka pelajari dengan materi prasyarat yang sudah mereka kuasai. Menurut Afifah (Badjeber dan Fatimah, 2017: 2) , apabila siswa telah mampu mengamati hubungan antar konsep, prinsip atau prosedur dengan benar serta mampu memberikan argumen untuk menjelaskan hal tersebut, siswa akan memperoleh pemahaman yang lebih mendalam dan juga meningkatkan kepercayaan diri mereka. Oleh karena itu agar siswa bisa lebih optimal dalam belajar matematika, mereka harus diberikan kesempatan untuk lebih memahami dan menggunakan hubungan- hubungan tersebut. Berdasarkan paparan tersebut diatas maka peneliti tertarik untuk melakukan penelitian dengan judul "Pengembangan Bahan Ajar Dengan Konteks Alat Berburu Tradisional Dayak Tabun Dalam Materi Bangun Ruang Sisi Datar Pada Siswa Kelas VIII SMP Negeri 01 Ketungau Tengah”.

\section{METODE PENELITIAN}

Metode penelitian yang digunakan pada penelitian ini adalah metode penelitian pengembangan (Research and Development) yang merupakan salah satu jenis dari metode penelitian. Secara umum metode penelitian diartikan secara ilmiah untuk mendapatkan data dengan tujuan dan kegunaan tertentu. Cara ilmiah bearti kegiatan penelitian itu didasarkan pada ciri-ciri keilmuan yaitu rasional, empiris, dan sistematis. (Sugiyono, 2017: 2). Rancangan dan prosedur penelitian yang digunakan dalam penelitian R\&D ini adalah model pengembangan 
Jurnal Lebesgue : Jurnal Ilmiah Pendidikan Matematika, Matematika dan Statistika

Hedrian Pilimon, Muhamad Firdaus, Hartono

Volume 2, No. 3, Desember 2021 hal.245-255

DOI Artikel : 10.46306/lb.v2i3.80

menurut Thiagajaran (Sugiyono,2017: 37) mengemukakan bahwa langkah-langkah penelitian dan pengembangan disingkat dengan 4-D yang merupakan perpanjangan dari Define (Pendefinisian), Design (Perancangan), Development (Pengembangan), dan Dessemination (Penyebaran). Akan tetapi, karena keterbatasan waktu, biaya, tenaga, dan subjek penelitian ini hanya meliputi satu sekolah dan satu kelas serta penelitian ini hanya ditunjukan untuk menyelesaikan permasalahan yang ada di SMP Negeri 01 Ketungau Tengah maka tahap yang digunakan hanya pada tahap yang ketiga yaitu tahap pengembangan (development) tidak sampai dengan tahap penyebaran (disseminate)

\section{HASIL DAN PEMBAHASAN}

Tahap pendefinisian ini dilakukan untuk mengidentifikasi kebutuhan berdasarkan analisis dari permasalahan yang ditemukan. Kegiatan yang dilakukan berupa:

Analisis awal pada tahap ini langkah pertama yang dilakukan peneliti adalah menentukan masalah. Setelah mengidentifikasi masalah yang dialami siswa, maka peneliti pun menentukan solusi yang akan ditawarkan. Saat melakukan tahap ini peneliti melakukan wawancara terhadap guru. Wawancara dilaksanakan pada tanggal 1 Maret 2020 diruangan guru. Wawancara ini bertujuan untuk menganalisis masalah yang dialami siswa. Hal-hal yang ditanyakan antara lain terkait siswa, biodata guru mata pelajaran matematika, materi pembelajaran, strategi pembelajaran, dan media pembelajaran.

Analisis Siswa pada tahap ini peneliti melakukan wawancara, peneliti menanyakan beberapa butir pertanyaan, sebelum melakukan wawancara peneliti mengucapkan salam terlebih dahulu, kemudian dilanjutkan dengan pertanyaan pertama yaitu izin untuk melakukan wawancara dengan guru matematika tersebut. Guru tersebut pun menjawab dengan mempersilahkan peneliti untuk memulai pertanyaan.

Butir pertanyaan kedua diisi dengan perkenalan dari peneliti, kemudian menanyakan nama guru matematika tersebut. Nama ibu guru tersebut adalah Aprilia Susanti, S.Pd. Butir pertanyaan ketiga adalah tentang jabatan ibu Aprilia Susanti di SMP Negeri 01 Ketungau Tengah. Beliau menjawab bahwa beliau adalah guru mata pelajaran matematika dan sebagai guru tetap disekolahan tersebut.

Butir pertanyaan keempat mengenai kurikulum dan model pembelajaran apa yang digunakan di sekolah tersebut. Beliau menjawab di sekolahan tersebut sudah menggunakan kurikulum 2013 dan model pembelajaran yang digunakan adalah model pembelajaran 
Jurnal Lebesgue : Jurnal Ilmiah Pendidikan Matematika, Matematika dan Statistika

Hedrian Pilimon, Muhamad Firdaus, Hartono

Volume 2, No. 3, Desember 2021 hal.245-255

DOI Artikel : 10.46306/lb.v2i3.80

konvensional dengan pendekatan saintifik. Butir pertanyaan kelima yaitu bagaimana ketertarikan siswa terhadap pelajaran matematika. Beliau menjawab bahwa ketertarikan siswa dengan matematika masih sangat kurang karena siswa masih menganggap bahwa matematika pelajaran yang susah.

Butir pertanyaan keenam yaitu masalah yang siswa hadapi pada saat proses pembelajaran berlangsung. Guru menjawab bahwa masalah yang siswa hadapi pada saat pembelajaran berlangsung yaitu siswa kekurangan bahan ajar untuk belajar, lalu siswa kesulitan menjawab soal-soal berbentuk cerita jika diberikan contoh matematika dengan kehidupan sehari-hari, khususnya pada materi bangun ruang sisi datar. Butir pertanyaan ketujuh adalah apakah ibu pernah menggunakan media lain sebagai penunjang dalam proses belajar mengajar. Beliau menjawab memberikan bahan ajar berupa print out dan itupun sangat jarang sekali. Butir pertanyaan kedelapan yaitu peneliti menawarkan untuk mengembangkan bahan ajar dengan konteks alat berburu tradisional dayak tabun dan diterapkan untuk kelas VIII di sekolah tersebut. Guru pun menjawab bahwa ide tersebut cukup bagus.

Butir pertanyaan kesembilan yaitu peneliti memberikan gambaran tentang bahan ajar yang akan dikembangkan dan menanyakan persetujuan dari guru tersebut. Peneliti pun diperbolehkan untuk mengembangkan bahan ajar di kelas dan di sekolah tersebut. Pertanyaan kesepuluh peneliti mengucapkan terima kasih atas kesediaan waktu beliau untuk diwawancarai dan memohon maaf apabila ada kata yang keliru. Beliau pun menyarankan agar rencana tersebut untuk segera dilaksanakan.

Analisis tugas pada tahap ini berdasarkan hasil wawancara tersebut guru menyimpulkan bahwa kurangnya pemahaman pada siswa jika diberikan contoh matematika jika dikaitkan dengan kehidupan sehari-hari. Oleh karena itu peneliti memilih materi bangun ruang sisi datar dengan sub materi balok untuk dijadikan materi dalam penelitian ini. Media pembelajaran yang digunakan di sekolah tersebut hanya menggunakan buku paket dan sesekali print out. Untuk itu peneliti menawarkan untuk mengembangkan bahan ajar dengan konteks alat tradisional dayak tabun yang diharapkan dapat memudahkan siswa untuk memahami tentang keterkaitan pembelajaran matematika dengan alat-alat tradisional dayak tabun.

Perumusan Tujuan Pembelajaran berdasarkan hasil pra observasi didapati siswa masih kesulitan menyelesaikan soal cerita jika diberikan contoh-contoh matematika yang dikaitkan dengan kehidupan sehari-hari pada materi bangun ruang sisi datar dengan sub materi balok . 
Jurnal Lebesgue : Jurnal Ilmiah Pendidikan Matematika, Matematika dan Statistika

Hedrian Pilimon, Muhamad Firdaus, Hartono

Volume 2, No. 3, Desember 2021 hal.245-255

DOI Artikel : 10.46306/lb.v2i3.80

Adapun materi, standar kompetensi, kompetensi dasar, kompetensi inti, dan tujuan pembelajaran.

Tahap perencanaan dilakukan untuk merancang produk pengembangan yang disesuaikan dengan permasalahan yang diperoleh di lapangan saat tahap pendefinisian. Tahap pengembangan terdiri dari 4 tahap, yaitu sebagai berikut: Penyusunan Instrument Tes, Pada tahap pertama ini peneliti menyusun kisi-kisi lembar validasi, kisi-kisi angket, dan kisi-ki soal uji coba. Kisi-kisi angket dalam lembar ahli materi yang disusun sebanyak 3 aspek yaitu, kelayakan isi (12 butir pertanyaan), kelayakan penyajian (7 butir pertanyaan), kelayakan bahasa (9 butir pertanyaan). Sedangkan kisi-kisi angket dalam lembar ahli media disusun hanya 1 aspek yaitu, kelayakan kegrafikan dengan 3 indikator penilaian antara lain ukuran bahan ajar (2 butir pertanyaan), desain sampul bahan ajar (5 butir pertanyaan), desain isi bahan ajar (7 butir pertanyaan). Tahap kedua, peneliti menyusun lembar validasi angket dan soal uji coba sesuai dengan kisi-kisi yang telah dibuat pada langkah pertama. Butir pertanyaan yang diperoleh dari ahli materi 28 butir pertanyaan dan ahli media 14 butir pertanyaan sehingga total pertanyaannya sebanyak 42 butir pertanyaan.

Pemilihan Media, pada tahap ini peneliti memutuskan untuk memilih mengembangkan bahan ajar (modul) matematika sebagai media dalam penelitian, format Secara garis besar bahan ajar (modul) matematika ini terdiri dari halaman sampul berwarna dan bergambar, kata pengantar, daftar isi, kompetensi inti (ki), dan kompetensi dasar (kd), judul materi pembelajaran, tujuan pembelajaran, isi, sesuai dengan kurikulum k-13, penyajian materi akan diberi warna untuk menarik perhatian dan minat baca siswa, materi yang disajikan sesuai dengan standar kompetensi dan kompetensi dasar, ringkasan materi, contoh soal dengan cara penyelesaiannya, latihan soal, kunci jawaban dan daftar pustaka. Desain awal pada tahap ini, kegiatan yang dilakukan adalah mendesain bahan ajar matematika tersebut.

Tahap pengembangan bertujuan untuk memperbaiki bahan ajar yang akan dikembangkan dengan melakukan evaluasi dan revisi sebelum menjadi produk yang valid, praktis, dan efektif.

Validasi digunakan untuk mengetahui kevalidan bahan ajar. Validasi dilakukan oleh 2 orang ahli dari dosen program studi pendidikan matematika sebagai ahli I dan II, serta 1 orang ahli dari SMPN 01 Ketungau Tengah sebagai sebagai ahli III. Masing-masing ahli menjadi ahli media dan ahli materi, dan validator soal uji coba serta validator angket. Artinya ketiga validator menilai dan memberikan saran apa saja yang harus diperbaiki dari bahan ajar dan menilai valid atau tidak bahan ajar matematika tersebut. 
Jurnal Lebesgue : Jurnal Ilmiah Pendidikan Matematika, Matematika dan Statistika

Hedrian Pilimon, Muhamad Firdaus, Hartono

Volume 2, No. 3, Desember 2021 hal.245-255

DOI Artikel : 10.46306/lb.v2i3.80

Sesuai dengan latar belakang dikembangkannya bahan ajar matematika ini, maka uji coba lapangan dilakukan di SMP Negeri 01 Ketungau Tengah pada siswa kelas VIII. Hari pertama penelitian pada tanggal 2 Maret 2020, guru matematika memberikan pengajaran kepada siswa kelas VIII dengan menerapkan bahan ajar modul matematika. Siswa terlihat antusias dalam mengikuti pembelajaran, baik dalam menerima materi, membahas contoh soal, serta mengerjakan soal-soal latihan yang terdapat dalam bahan ajar matematika tersebut. Hari kedua pada tanggal 3 Maret 2020, guru meminta siswa untuk mengerjakan soal post test dengan menggunakan soal uji coba. Pengerjaan post test ini digunakan untuk melihat keefektifan dari bahan ajar tersebut. Soal diberikan kepada siswa dengan waktu pengerjaan selama 2 x 35 menit. Hari ketiga yaitu pada tanggal 4 Maret 2020, guru membagikan angket respon kepada seluruh siswa untuk menilai bahan ajar yang telah digunakan, angket berfungsi untuk menilai kepraktisan dari bahan ajar tersebut.

Setelah diuji coba lapangan, bahan ajar ini siap dikemas menjadi produk akhir. Guru matematika di tempat uji coba tidak memberikan saran apapun. Beliau hanya berpendapat bahwa bahan ajar ini memudahkan ia dalam menyampaikan materi dan dapat membantu siswa untuk lebih mudah memahami materi dalam bahan ajar ini. Dengan demikian, bahan ajar ini sudah bisa dicetak kembali dan digunakan sebagai produk akhir.

Pengembangan bahan ajar ini menggunakan prosedur penelitian 4-D yang dikembangkan oleh Thiagajaran pada tahun 1974. Bahan ajar ini terdiri dari 4 tahap pengembangan, yaitu define (pendefinisian), design (perancangan), development (pengambangan), desseminate (penyebaran). Namun dengan beberapa pertimbangan, peneliti menggunakan 3 tahapan dalam penelitian ini, yaitu hanya sampai pada tahap pengembangan.

Tahap pertama dalam penelitian ini mencakup analisis siswa dan analisis kebutuhan, sehingga diperoleh kesimpulan masalah apa saja yang didapatkan serta bagaimana solusinnya. Tahap kedua melakukan perancangan, mulai dari merancang lembar instrumen penelitian atau angket, sampai dengan merancang bahan ajar. Tahap ketiga adalah validasi, pelaksanaan uji coba hingga perbaikan produk akhir.

Pengembangan bahan ajar dengan konteks alat tradisional dayak Tabun dimana maksud dan tujuan peneliti disini adalah menerapkan contoh-contoh alat tradisional dayak tabun yang berkaitan dengan bentuk bangun pada pembelajaran matematika dengan maksud agar siswa lebih mudah memahami dan mengerti ketika diberikan soal matematika. Bahan ajar ini terdiri dari sampul, kata pengantar, pendahuluan, daftar isi, kompetensi inti (KI), kompetensi dasar 
Jurnal Lebesgue : Jurnal Ilmiah Pendidikan Matematika, Matematika dan Statistika

Hedrian Pilimon, Muhamad Firdaus, Hartono

Volume 2, No. 3, Desember 2021 hal.245-255

DOI Artikel : 10.46306/lb.v2i3.80

(KD), judul materi pembelajaran, materi, ringkasan materi, contoh soal serta penyelesaian, latihan soal, kunci jawaban, daftar pustaka.

Untuk mengetahui kevalidan suatu bahan ajar maka perlu dilakukan validasi, validasi dilakukan oleh 2 orang ahli dari dosen program studi pendidikan matematika dan 1 orang ahli dari SMPN 01 Ketungau Tengah selaku ahli III. Masing-masing ahli menjadi ahli media dan ahli materi, dan validator soal uji coba serta validator angket. Artinya ketiga validator menilai dan memberikan saran apa saja yang harus diperbaiki dari bahan ajar dan menilai valid atau tidak bahan ajar matematika tersebut. Berikut adalah hasil penilaian bahan ajar:

Tabel 1. Analisis Materi dan Media Kevalidan Produk Pengembangan

\begin{tabular}{cccc}
\hline No. & Ahli & Persentase & Keterangan \\
\hline 1 & Ahli Materi 1 & $84 \%$ & Valid \\
\hline 2 & Ahli Materi II & $78,66 \%$ & Valid \\
\hline 3 & Ahli Materi III & $80,66 \%$ & Valid \\
\hline 4 & Ahli Media I & $80,74 \%$ & Valid \\
\hline 5 & Ahli Media II & $78,51 \%$ & Valid \\
\hline 6 & Ahli Media III & $82,22 \%$ & Valid \\
\hline
\end{tabular}

Berdasarkan tabel 1. maka diperoleh hasil kevalidan bahan ajar adalah dalam kriteria valid dan dapat diujicobakan.

Untuk mengetahui kepraktisan pada penelitian ini adalah didapat dari hasil angket respon siswa dan guru diperoleh:

Rata-rata respon siswa adalah 84,75\% dijumlahkan dangan hasil respon guru adalah $84 \%$ kemudian dibagi 2 maka diperoleh 84,37 \% dengan kategori praktis.

Untuk hasil pengerjaan post test digunakan untuk mengetahui keefektifan bahan ajar yang dikembangkan, posttest yang diberikan berupa soal essay pada materi balok yang terdiri dari 5 soal posttest. Hasil penilaian keefektifan bahan ajar matematika adalah sebagai berikut: 


$$
\begin{gathered}
\mathrm{HR}=\frac{\text { Jumlah siswa yang mendapat nilai } \geq 60}{\text { Jumlah Siswa yang mengikuti tes }} \times 100 \% \\
\mathrm{HR}=\frac{20}{29} \times 100 \%=68,96 \%
\end{gathered}
$$

Dari hasil penilaian sebesar 68,96 \% maka keefektifan bahan ajar matematika tersebut dikategorikan efektif.

Berdasarkan hasil penelitian, diketahui bahwa bahan ajar dengan konteks alat tradisional dayak tabun efektif terhadap hasil belajar siswa dalam materi bangun ruang sisi datar. Hasil penelitian juga menunjukan bahwa bahan ajar matematika layak digunakan sebagai bahan ajar di sekolah yang ditunjukan dari aspek kevalidan, kepraktisan dan keefektifan. Hal ini sesuai dengan pendapat Nieeven (Haviz, 2013: 32) yang menyatakan bahwa kualitas hasil penelitian pengembangan dipengaruhi oleh beberapa kriteria, yaitu validity (kevalidan), practicality (kepraktisan), dan effectiveness (keefektifan).

\section{KESIMPULAN}

Berdasarkan hasil penelitian dapat diambil kesimpulan bahwa pengembangan bahan ajar dengan konteks alat berburu tradisional dayak tabun dalam materi bangun ruang sisi datar pada siswa kelas VIII SMPN 01 Ketungau Tengah, harus memperhatikan beberapa aspek berkaitan dengan kelayakan bahan ajar yang akan diuji coba. Agar dapat memperoleh kriteria layak harus melalui langkah-langkah sesuai prosedur pengembangan. Dalam penelitian ini yaitu mengacu pada model pengembangan menurut Thiagajaran yang mengemukakan langkah-langkah penelitian dan pengembangan yang disingkat 4-D yang merupakan perpanjangan dari Define (Pendefinisian), Design (Perancangan), Development (Pengembangan), dan Dessemination (Penyebaran), namun dalam penelitian ini karena keterbatasan waktu, biaya, tenaga, dan subjek penelitian ini hanya sampai pada tahap yang ketiga yaitu tahap Development (Pengembangan) tidak sampai dengan tahap Dessemination (Penyebaran). 
Jurnal Lebesgue : Jurnal Ilmiah Pendidikan Matematika, Matematika dan Statistika

Hedrian Pilimon, Muhamad Firdaus, Hartono

Volume 2, No. 3, Desember 2021 hal.245-255

DOI Artikel : 10.46306/lb.v2i3.80

Oleh karena itu hasil yang dapat disimpulkan dari penelitian ini adalah:

1. Bahan ajar dengan konteks alat berburu tradisional dayak tabun diperoleh kategori valid dalam materi bangun ruang sisi datar pada siswa kelas VIII SMP Negeri 01 Ketungau Tengah.

2. Bahan ajar dengan konteks alat berburu tradisional dayak tabun diperoleh kategori praktis dalam materi bangun ruang sisi datar pada siswa kelas VIII SMP Negeri 01 Ketungau Tengah.

3. Bahan ajar dengan konteks alat berburu tradisional dayak tabun diperoleh kategori efektif dalam materi bangun ruang sisi datar pada siswa kelas VIII SMP Negeri 01 Ketungau Tengah.

\section{DAFTAR PUSTAKA}

Arikunto, S. (2015). Dasar-dasar Evaluasi Pendidikan. Jakarta: Bumi Aksara. Budiyono. (2011). Penilaian Hasil Belajar. Surakarta: Universitas Sebelas Maret.

Darmadi, H. 2014. Metode Penelitian Pendidikan dan Sosial. Bandung: Alfabeta.

Darmadi, H. 2016. Dayak Asal Asul dan Penyebarannya di Bumi Borneo(1). Jurnal Pendidikan Sosial, 3(2), 322-340.

Daryanto. (2010). Media Visual untuk Pengajaran Teknik. Bandung: Tarsito.

Hemiati, N. (2018). Pengembangan Bahan Ajar Matematika Berbasis Buku Fabel Berkarakter Pada Materi Persegi Panjang Kelas VII MTS AL-HUDA. Skripsi pada Fakultas MIPA dan Teknologi Institut Keguruan dan Ilmu Pendidikan. Pontianak: tidak diterbitkan.

Jihad, A., Haris, A. (2013). Evaluasi Pembelajaran. Yogyakarta: Multi Pressindo.

Laurens, T. 2016. Analisis Etnomatematika Dan Penerapannya Dalam Meningkatkan Kualitas Pembelajaran. Prodi Pend.Matematika STKIP PGRI Sumbar, 3 (1), 86-96.

Lestari, K.E., Yudhanegara, M.R. (2015). Penelitian Pendidikan Matematika. Bandung: PT. Refika Aditama.

Putri, L. I. 2017. Eksplorasi Etnomatematika Kesenian Rebana Sebagai Sumber Belajar Matematika Pada Jenjang MI. Jurnal ilmiah“ Pendidikan Dasar”, 4 (1), 21-31.

Rakhmawati, M. R. 2016. Aktivitas Matematika Berbasis Budaya Pada Masyarkat Lampung. Jurnal Pendidikan Matematika, 7(2), 221-230.

Septian, D.P. 2017. “Alat-Alat Tradisional Etnis Dayak Tabun Dalam Pembelajaran Matematika di Sekolah". Fakultas Pendidikan MIPA dan Teknologi IKIP PGRI Pontianak.

Sugiyono, (2016). Metode Penelitian Pendidikan. Bandung: Alfabeta.

Sugiyono, (2016). Metode Penelitian dan Pengembangan. Bandung: Alfabeta.

Tandililing, E. (2013). Pengembangan Pembelajaran Matematika Sekolah dengan Pendekatan Etnomatematika Berbasis Budaya Lokal Sebagai Upaya untuk Meningkatkan Kualitas Pembelajaran Matematika di Sekolah. Prosiding Seminar Nasional Matematika dan Pendidikan Matematika. Yogyakarta: FMIPAUNY.

Yuliza, A. C. (2018). Pengembangan LKS Berbasis Problem Posing pada Materi Segitiga Terhadap Kemampuan Pemecahan Masalah Matematis Siswa di Kelas VII MTS N 2. Skripsi pada Fakultas Mipa dan Teknologi Institut Keguruan dan Ilmu Pendidikan. Pontianak: tidak diterbitkan. 
Jurnal Lebesgue : Jurnal Ilmiah Pendidikan Matematika, Matematika dan Statistika

Hedrian Pilimon, Muhamad Firdaus, Hartono

Volume 2, No. 3, Desember 2021 hal.245-255

DOI Artikel : 10.46306/lb.v2i3.80

Widoyoko, E. P. (2009). Evaluasi Program Pembelajaran Panduan Praktis bagi Pendidikan dan Calon Pendidik. Yogyakarta: Pustaka Belajar. 